\title{
Pendidikan Toleransi Terhadap Remaja Muslim dan Kristen di Salatiga (Studi Terhadap Perayaan Halal Bihalal dan Natal Bersama di Desa Pengilon Mangunsari Sidomukti Kota Salatiga)
}

\author{
Ahmad Faidi ${ }^{*}$ \\ IAIN Salatiga, Indonesia*1 \\ *1email: ahmadfaidi86@gmail.com
}

\begin{abstract}
Cultivating the values of tolerance towards adolescents, especially through the celebration of Islamic and Christian holidays together, is one of the dominant factors in preserving the culture of tolerance among the people of Salatiga City. This type of naturalistic qualitative research, using a critical analytical descriptive approach, makes the people of Pengilon Village as its material objects. This research found that the celebration of Islamic and Christian holidays in Pengilon turned out to have a different function compared to other regions. Apart from functioning as a religious ritual, the Christmas and Halal-Bihalal Celebration "together" also means a medium for tolerance education for children and adolescents in Salatiga City.
\end{abstract}

Keywords: Halal-bihalal Together, Christmas Together, Internalization of Tolerance Values.
Artikel Info

Received:

25 August 2020

Revised:

20 October 2020

Accepted:

11 November 2020

Published:

03 December 2020

\section{Abstrak}

Penanaman nilai-nilai toleransi terhadap kalangan remaja, khususnya melalui perayaan hari-hari besar Islam dan Kristen secara bersama-sama, menjadi salah satu faktor dominan dalam pelestarian kultur toleransi di kalangan masyarakat Kota Salatiga. Jenis penelitian kualitatif naturalistik ini, dengan menggunakan pendekatan deskriptif analitis kritis, menjadikan masyarakat Desa Pengilon sebagai objek materialnya. Penelitian ini menemukan bahwa perayaan hari-hari besar Islam dan Kristen di Pengilon ternyata memiliki fungsi yang berbeda dibandingkan dengan daerah-daerah lainnya. Perayaan Natal dan Halal-Bihalal "bersama", selain berfungsi sebagai ritual keberagamaan, juga bermakna sebagai media 
pendidikan toleransi terhadap kalangan anak-anak dan remaja Kota Salatiga.

\section{Kata Kunci: Halal-Bihalal Bersama, Natal Bersama Internalisasi Nilai Toleransi.}

\section{A. Pendahuluan}

Berbeda dengan daerah lain, kehidupan horizontal umat dengan beragam latar belakang etnis, budaya, dan agama yang harmonis itu tercermin di sebuah kota kecil bagian tengah Pulau Jawa, Salatiga. Kota Salatiga menjadi diorama Kepulauan Indonesia yang merepresentasikan leburnya ego-ego etnosentrisme. Indeks kota toleran yang dirilis pada 2015 oleh Setara Institute, Salatiga tergolong kota yang masyarakatnya paling mampu bertenggang rasa. Bahkan, pada tahun 2018 lalu, Setara Institute juga merilis hasil penelitiannya tentang kota paling toleran di Indonesia. Hasil reasearch tersebut menunjukkan bahwa Salatiga menjadi kota paling toleran nomor 2 di Indonesia dengan perolehan nilai 6.477.

Sedangkan kota paling toleran nomor satu di Indonesia diperoleh oleh Kota Lampung yang memperoleh nilai 6.613. Metode yang digunakan oleh Setara Institute dalam menentukan Kota paling toleran di Indonesia tersebut melalui empat variabel penilaian yaitu; a) Regulasi Pemerintah Kota; b) Tindakan Pemerintah; c) Regulasi Sosial; dan d) Demografi Agama.

Berdasarkan pada keempat variabel tersebut maka Salatiga terpilih sebagai kota paling toleran nomor dua di Indonesia. Tentu, kultur toleransi yang telah tertanam erat pada pola hidup masyarakat Salatiga disebabkan oleh berbagai faktor yang begitu kompleks. Akan tetapi, pada penelitian ini focus kajiannya adalah tentang Sistem Regulasi Sosial masyarakat Salatiga, khususnya terkait dengan kultur internalisasi niali-nilai toleransi terhadap kalangan remaja di kota Salatiga.

\section{Penelitian ini fokus mengkaji} tentang bagaimana masyarakat Salatiga mendidik para generasi mudanya untuk senantiasa hidup toleran antara satu sama lain. Objek yang dipilih untuk kajian ini adalah kultur pendidikan toleransi yang diterapkan oleh masyarakat Desa Pengilon Kelurahan Mangunsari, Kecamatan Sidomukti, Kota Salatiga. 


\section{INTIQAD: JURNAL AGAMA DAN PENDIDIKAN ISLAM}

ISSN 1979-9950 (print) || ISSN 2598-0033 (online), http://jurnal.umsu.ac.id/index.php/intiqad DOI: 10.30596/intiqad.v12i2.5089

Vol. 12, No. 2 (December 2020)

Pemilihan daerah Pengilon sebagai objek penelitian didasarkan pada pola hidup dan kultur yang khas dibandingkan dengan beberapa daerah lain di Salatiga, khususnya terkait dengan perayaan harihari besar agama Islam dan Kristen.

Daerah Pengilon, berbagai macam praktek keagamaan dilaksanakan dengan harmonis oleh warganya. Bahkan, masyarakat Pengilon juga menjadikan momen-momen hari besar keagamaan sebagai media atau ajang penanaman nilai-nilai toleransi bagi kalangan remaja Pengilon.

Tentu, penanaman nilai-nilai toleransi terhadap masyarakat Kota Salatiga yang dimulai sejak usia dini, menjadi gerakan akar rumput bagi diperolehnya gelar kota toleran nomor dua oleh Salatiga. Salah satu contoh misalnya pada pelaksanaan upacaraupacara besar hari Islam dan Kristen di Kota Salatiga. Remaja diwajibkan berperan aktif dalam masing-masing pelaksanaan upacara-upacara keagamaan tersebut. Dalam pelaksanan upacara Halal-bilhalal Islam, para remaja Kristen diwajibkan untuk turut serta meramaikan dan mensukseskan acara tersebut. Demikian juga pada pelaksanaan upacara Hari besar agama Kristen, para remaja Muslim diwajibkan untuk berperan dalam mendukungt suksesnya acara.

Berangkat dari realitas semacam itulah maka penelitian ini menjadi cukup menarik untuk diteliti. Pola yang demikian dapat dijadikan cerminan dan rujukan oleh masyarakat Indonesia pada umumnya untuk menciptakan pola kehidupan yang harmonis, rukun, damai, dan aman.

\section{B. Metode Penelitian}

Jenis penelitian yang dianggap tepat dalam penelitian ini adalah kualitatif naturalistik. Prosedur penelitian kualitatif tersebut mampu menghasilkan data deskriftif yang berupa kata-kata, simbol-simbol bahasa, baik yang tertulis maupun lisan, serta perilaku orang-orang yang dapat diamati. Dengan demikian, informasi atau datadata yang akurat tentang fenomena tertentu dapat diperoleh secara akurat. Adapun metode pendekatan yang digunakan adalah pendekatan deskriptif analitis kritis.

Penelitian kualitatif dipandang cocok karena menurut Bodgan \& Biklen penelitian kualitatif bersifat ilmiah dan menghendaki keutuhan: 


\section{INTIQAD: JURNAL AGAMA DAN PENDIDIKAN ISLAM}

ISSN 1979-9950 (print) || ISSN 2598-0033 (online), http://jurnal.umsu.ac.id/index.php/intiqad DOI: 10.30596/intiqad.v12i2.5089

Vol. 12, No. 2 (December 2020)

We use qualitative research as an umbrella term to refer to several research strategies that share certain characteristic. The data collected has been termed soft, that is, rich in description of people, place, and conversation, and not easily handled by statistical procedures. “... In education, qualitative reseach is frequently called 'naturalistic' because the researcher hangs around where the events he or she is interested in naturally occur. And the data is gathered by people engaging in natural behavior: talking, visiting, looking, eating, and so on (Bodgam C. \& Biklen, 1982).

Pendekatan kualitatif diharapkan mampu mengarahkan penelitian menuju pemahaman dan penafsiran yang mendalam mengenai makna dari fakta dan informasi di lapangan yang relevan dengan tema penelitian. Pada dasarnya, Pendekatan kualitatif berupaya membedah permasalahan penelitian secara komprehensif, holistik, integratif, dan mendalam.

Hal itu dapat diperoleh melalui proses pengamatan terhadap interaksi antara individu-individu dengan lingkungan sekitarnya. Meski demikian, penelitian ini tetap dilakukan dalam situasi yang wajar (natural setting), di mana peneliti harus terjun ke lapangan secara intensif dan dalam waktu yang lama (Nasution, 1988).
Guba, sebagaimana dikutip oleh Noeng Muhadjir (2002), menekankan bahwa setidaknya ada empat belas alasan metodologis terkait penggunaan metode naturalistik kualitatif dalam sebuah penelitian.

Terlepas dari itu, secara lebih spesifik, penelitian ini menggunakan desain studi kasus (case study): sebuah penelitian terhadap suatu "kesatuan sistem". Kesatuan yang dimaksudkan di sini dapat berupa kegiatan, peristiwa, program, atau sekelompok individu yang terikat oleh tempat, waktu, atau ikatan tertentu. Penelitian studi kasus merupakan penelitian yang diarahkan untuk mengumpulkan data, menginterpretasi makna, memperoleh pemahaman atau informasi dari kasus tersebut (Sukmadinata, 2005). Meski demikian satu kasus tertentu tidak dapat dianggap telah mewakili populasi tertentu. Kesimpulan yang diperoleh dari studi kasus bersifat sepesifik dan hanya berlaku untuk kasus tersebut pula. Dalam konteks inilah maka dapat dikatakan bahwa tiap-tiap kasus bersifat unik dan memiliki karakteristik tersendiri yang berbeda dengan kasus lainnya. Hal ini pulalah yang juga akan 


\section{INTIQAD: JURNAL AGAMA DAN PENDIDIKAN ISLAM}

ISSN 1979-9950 (print) || ISSN 2598-0033 (online), http://jurnal.umsu.ac.id/index.php/intiqad DOI: 10.30596/intiqad.v12i2.5089

Vol. 12, No. 2 (December 2020)

diungkap secara utuh dalam penelitian ini.

Dalam penelitian ini digunakan beberapa teknik pengumpulan data yaitu: pengamatan berperanserta (participant observation), wawancara mendalam (indepth interview), dan dokumentasi. Metode ini dimaksudkan untuk mendapatkan kesatuan data dan kesimpulan. Oleh karena itu, kehadiran peneliti dalam setting penelitian, merupakan tuntutan agar bisa memahami dan mengungkap kasus-kasus, baik yang bersifat positif maupun negatif yang terkait pada proses pendidikan toleransi dalam upacara-upacara hari besar keagamaan di Desa Pengilon Kota Salatiga.

\section{Hasil dan Pembahasan}

\section{Perayaan Upacara Halal-Bihalal}

\section{Bersama di Dusun Pengilon}

Sudah menjadi tradisi masyarakat Muslim di Indonesia, selalu merayakan hari-hari besar Islam dengan upacara atau selamatan. Hal demikian tentu tidak lepas dari kultur dan tradisi masyarakat Indonesia sejak dahulu. Selamatan bagi masyarakat Jawa merupakan sebuah upaya menjaga keharmonisan dengan lingkungan sekitar, baik itu dengan manusia maupun dengan alam sekitar.

Upacara-upacara selamatan dan perayaan hari-hari besar juga masih mendarah daging di kalangan masyarakat Muslim. Bagi sebagian besar masyarakat Muslim Indonesia, keagamaan mereka seakan kurang afdhal jika tidak disertai dengan upacaraupacara selamatan menyambut hari-hari besar Islam.

Tidak berbeda dari umat Islam pada umumnya, masyarakat non-Muslim di Pengilon juga turut serta merayakan hari-hari besar Islam. Tentu, dalam setiap melaksanakan upacara hari-hari besar Islam Masyarakat Pengilon memiliki tradisi yang berbeda dari masyarakat Muslim di daerah lainnya. substansinya mungkin sama, tetapi tata cara pelaksanannya pastilah berbeda. Hal demikian tentu tidak lepas dari pengaruh lingkungan sosial masyarakat sekitarnya.

Tidak berbeda dengan masyarakat Muslim Indonesia lainnya, masyarakat Muslim Pengilon juga memilkiki beberapa perayaan hari besar Islam. Beberapa perayaan hari besar Islam yang kerap kali dirayakan oleh umat Islam Pengilon di antaranya Nuzulul Qur'an, 


\section{INTIQAD: JURNAL AGAMA DAN PENDIDIKAN ISLAM}

ISSN 1979-9950 (print) || ISSN 2598-0033 (online), http://jurnal.umsu.ac.id/index.php/intiqad DOI: 10.30596/intiqad.v12i2.5089

Vol. 12, No. 2 (December 2020)

Idul Fitri, Idul Adha, dan Lain sebagainya.

Akan tetapi, dalam penelitian ini lebih fokus mengkaji acara halal-bihalal bersama yang dilaksanakan oleh masyarakat Pengilon. Dari beberapa upacara tersebut di atas, hanya acara halal-bihalal yang dianggap mewakili dari tema penelitian ini.

Halal Bihalal adalah salah satu tradisi khas atau budaya khas dari Negara Indonesia. artinya, acara halal bihalal ini hanya dilakukan oleh masyarakat mHuslim di Indonesia. Karena itulah maka tradisi perayaan halal-bihalal dapat diakatakan sebagai kebudayaan asli masyarakat Indonesia.

$$
\text { Dalam perkembangannya, }
$$
perayaan halal-bihalal menjadi cukup beragam. pada masyarakat pedesaan, halal-bihalal biasanya dilaksanakan dengan cara saling berkunjung ke sanak famili maupun tetangga sekitar. Sedangkan di masyarakat Kota, halalbihalal dilaksanakan hanya dalam satu malam saja dimana seluruh warga sekitar harus menghadiri forum tersebut untuk bersilaturrahim dan saling maafmemaafkan satu sama lain. Tentu kondisi ini dilatar-belakangi oleh lingkungan sosial perkotaan yang sebagian besar masyarakatnya adalah kaum pekerja yang tidak memiliki banyak waktu untuk bersilaturrahim ke rumah-rumah warga satu persatu. Oleh karena itu, demi efektifitas waktu itulah maka diadakanlah acara halal-bihalal.

Masyarakat Muslim Pengilon memang termasuk pada kategori masyarakat perkotaan yang sebagian besar pekerjanya memiliki kesibukan yang cukup padat. Oleh karena itu, masyarakat Pengilon memilih untuk melaksanakan halal-bihalal yang dirasakan lebih efektif.

Perayaan halal-bihalal di Pengilon tentu berbeda dengan perayaan halalbihalal di tempat lainnya. Secara penamaan, jika di tempat-tempat lainnya hanya disebut sebagai acara halalbihalal, tetapi di pengilon disebut dengan "halal-bihalal bersama." Hal ini akan kami bahas lebih detil pada sub bagian Nilai Toleransi pada Aspek Penamaan Acara Halal-Bihalal dan Natal.

Salah satu contoh susunan acara Halal-Bihalal Bersama yang dilaksanakan di kalangan masyarakat Desa Pengilon dapat dilihat pada tabel berikut. 


\section{INTIQAD: JURNAL AGAMA DAN PENDIDIKAN ISLAM}

ISSN 1979-9950 (print) || ISSN 2598-0033 (online), http://jurnal.umsu.ac.id/index.php/intiqad DOI: 10.30596/intiqad.v12i2.5089

Vol. 12, No. 2 (December 2020)

Tabel.1

\begin{tabular}{|r|l|}
\hline \multicolumn{2}{|c|}{$\begin{array}{l}\text { SUSUNAN ACARA } \\
\text { Halal-bihalal Bersama } \\
\text { Desa Pengilon }\end{array}$} \\
\hline $\mathbf{1 .}$ & Pembukaan \\
\hline $\mathbf{2 .}$ & Pembacaan kalam ilahi \\
\hline $\mathbf{3 .}$ & $\begin{array}{l}\text { Sambutan oleh panitia, Ketua } \\
\text { RT, dan Ketua RW }\end{array}$ \\
\hline $\mathbf{4 .}$ & $\begin{array}{l}\text { Istirahat dan Pembagian } \\
\text { Dorprise khusus remaja dan } \\
\text { anak-anak }\end{array}$ \\
\hline $\mathbf{5 .}$ & Tausiyah \\
\hline $\mathbf{6 .}$ & Doa bersama \\
\hline $\mathbf{7 .}$ & $\begin{array}{l}\text { Pembagian Dorprice khusus } \\
\text { remaja dan anak-anak }\end{array}$ \\
\hline $\mathbf{8 .}$ & Penutup \\
\hline $\mathbf{9 .}$ & Salam \\
\hline $\mathbf{1 0}$ & Foto Bersama \\
\hline
\end{tabular}

Menurut Bapak RW III Desa Pengilon, perayaan Halal Bihalal Bersama diadakan tidak hanya terbatas untuk masyarakat Muslim saja, akan tetapi warga non-Muslim juga diwajibkan untuk hadir dan terlibat adalam acara tersebut. Lebih dari itu, seluruh Warga RT V RW III Pengilon diwajibkan untuk membantu panitia pelaksana dalam mensukseskan acara halal-bihalal yang diadakan oleh masyarakat Muslim.

Dengan demikian, dapat dikatakan bahwa Masyarakat Non-Muslim juga harus menjadi peserta aktif dalam kegiatan halal-bihalal. Akan tetapi, bukan lantas mereka, Warga Non
Muslim, harus terlibat dalam setiap aspek acara. Para warga non Muslim hanya boleh mensupport dan memberikan bantuan terbatas pada halhal yang non substansial. Artinya, warga sudah sama-sama paham dimana letak dan tugasnya masing-masing.

Beberapa aspek halal-bihalal yang bisa disupport dan ditangani langsung oleh masyarakat non-Muslim misalnya; mempersiapkan tempat acara; sumbangan dana acara, mempersiapkan hidangan; serta dalam acara-acara non inti seperti halnya pada acara pembagian dorprice. Uniknya lagi, pembagian dorprice tidak hanya diperuntukkan kepada kalangan anak-anak dan remaja Muslim saja, tetapi juga dibagikan kepada anak-anak dan remaja non Muslim. Sistem dorprice ini dibagikan secara merata agar setiap anak-anak dan remaja Kristen yang hadir merasa senang dan bahagia menghadiri acara tersebut, meski itu bukan perayaan agamanya sendiri.

\section{Perayaan Natal Bersama di Pengilon}

Tidak jauh berbeda dengan tradisi masyarakat Muslim di Pengilon, perayaan Natal oleh penganut agama Kristen di Pengilon juga dinamai dengan 


\section{INTIQAD: JURNAL AGAMA DAN PENDIDIKAN ISLAM}

ISSN 1979-9950 (print) || ISSN 2598-0033 (online), http://jurnal.umsu.ac.id/index.php/intiqad DOI: $10.30596 /$ intiqad.v12i2.5089

Vol. 12, No. 2 (December 2020)

acara Natal Bersama. Dalam konteks ini, tentu penamaan Halal-Bihalal Bersama dan Natal Bersama bukan tanpa ada maksud dan tujuan tertentu. Penamaan tersebut secara gamblang menyatakan bahwa perayaan Kristen tersebut tidak hanya melibatkan para penganut agamannya masing-masing, tetapi mereka mengajak warga di luar mereka untuk hadir dan mensupport kegiatan secara bersama-sama.

Terlepas dari hal itu, sebelum kita terlalu jauh membahas tentang Natal sebagai media penanaman nilai-nilai toleransi, akan disajikan terlebih dahulu bagaimana pelaksanaan Natal Bersama di Pengilon. Berikut kami sajikan satu contoh susunan acara pelaksanaan Natal Bersama oleh Masyarakat Pengilon.

Tabel. 2

\begin{tabular}{|l|l|}
\hline \multicolumn{1}{|c|}{$\begin{array}{c}\text { SUSUNAN ACARA } \\
\text { Natal Bersama } \\
\text { Desa pengilon }\end{array}$} \\
\hline & \multicolumn{1}{|c|}{ IBADAH } \\
\hline & SEREMONIAL \\
\hline & Ketua Panitia Natal \\
\hline & Perwakilan undangan \\
\hline & $\begin{array}{l}\text { Kepala Desa setempat atau yang } \\
\text { mewakili }\end{array}$ \\
\hline HIBURAN \\
\hline $\begin{array}{l}\text { Persembahan Pujian dan tarian } \\
\text { Anak Sekolah Minggu }\end{array}$ \\
\hline Persembahan Pujian Kaum Ibu \\
\hline Drama Pemuda Remaja \\
\hline Persembahan Pujian Kaum Bapak \\
\hline
\end{tabular}

\begin{tabular}{|l|l|}
\hline & \multicolumn{3}{|l|}{ PEMBAGIAN BINGKISAN } \\
\hline & FOTO BERSAMA \\
\hline & MAKAN BERSAMA DAN \\
RAMAH TAMAH (Teks Susunan \\
Acara Perayaan Natal Bersama, \\
2017)
\end{tabular}

Melihat dari susunan acara Natal Bersama yang dilaksanakan oleh Masyarakat Pengilon pada tahun 2017 lalu, dapat disimpulkan bahwa secara umum Acara Perayaan Natal bersama tersebut dapat dibagikan menjadi 6 bagian; yaitu Ibadah, Perayaan, dan Hiburan, Pembagian Bingkisan, Foto Bersama, dan Makan Bersama.

Acara pertama, perayaan Natal dibuka dengan acara ibadah yang dilakukan oleh masyarakat Kristiani. Tentu, dapat dikatakan bahwa bagian acara inilah yang menjadi acara paling inti dalam perayaan Natal. Pasalnya, melalui bagian acara yang pertama ini para Jemaat Kristiani secara bersamasama membaca dan menyenandungkan ayat-ayat dalam injil, khususnya yang berkaitan dengan kesucian Yesus.

Pada bagian acara yang kedua, yaitu Perayaan Natal, bisanya diisi dengan seremonial. Acara seremonial ini diisi dengan sambutan-sambutan, yaitu sambutan dari Ketua Panitia, Ketua RT, 


\section{INTIQAD: JURNAL AGAMA DAN PENDIDIKAN ISLAM}

ISSN 1979-9950 (print) || ISSN 2598-0033 (online), http://jurnal.umsu.ac.id/index.php/intiqad DOI: $10.30596 /$ intiqad.v12i2.5089

Vol. 12, No. 2 (December 2020)

dan Ketua RW. Para pejabat struktural di Desa Pengilon memiliki peran cukup dominan dalam bagian acara ini. Pasalnya, sesi ini memang dikhususkan untuk memberikan kesempatan kepada para pejabat Pemerintahan di Lingkungan desa Pengilon untuk memberikan sambutan, pesan, dan harapannya dari pelaksanaan natal bersama tersebut.

Acara yang ketiga, yakni acara Hiburan. Sebagaimana sebutannya, sesi ini sebagian besar diisi dengan menyanyikan lagu-lagu. Tetapi, dimensi sakralitas perayaan Natal tetap menjadi penekanan utama. Hal demikian cukup nampak dalam pemilihan lagu yang seluruhnya bermakna pujian terhadap Sang Yesus. Beberapa penampilan yang dipersembahkan dalam acara ini adalah Persembahan Pujian dan tarian Anak Sekolah Minggu, Persembahan Pujian Kaum Ibu, Drama Pemuda Remaja, Persembahan Pujian Kaum Bapak, dan Persembahan Pujian Majelis Jemaat.

Sedangkan tiga sesi setelahnya, yaitu pembagian bingkisan, foto bersama, dan sesi makan bersama dan ramah-tamah merupakan acara bersama yang dipersembahkan untuk para jamaah dan seluruh undangan yang hadir, baik dari kalangan umat Kristiani maupun dari kalangan non Kristen.

\section{Pendidikan Toleransi pada}

Kalangan Remaja Dusun Pengilon dalam acara Halal-Bihalal Bersama dan Natal Bersama

Nilai-nilai toleransi dalam kehidupan sehari-hari masyarakat Kota Salatiga telah menjelma kultur yang seakan tak terpisahkan dari masyarakat Kota Salatiga. Tentu, pembentukan kultur toleransi ini didukung oleh berbagai macam faktor seperti regulasi pemerintah, respon pemerintah dalam menangani kasus-kasus ketegangan masyarakat beragama, regulasi sosial, dan beberapa faktor lainnya.

Pembentukan kultur toleransi, khususnya terhadap kalangan remaja Kota Salatiga sebagai generasi penerus era milenial, merupakan tantangan tersendiri bagi pelestarian kultur toleransi di kalangan remaja kota Salatiga. Hoax yang bersebaran di media sosial, tentu dapat menjadi virus yang dapat menggerus nilai-nilai toleransi di kalangan pemuda dan remaja Kota Salatiga. Dengan demikian, jika masyarakat Kota Salatiga tidak memiliki strategi antisipatif untuk melindungi generasi muda mereka dari virus-virus 


\section{INTIQAD: JURNAL AGAMA DAN PENDIDIKAN ISLAM}

ISSN 1979-9950 (print) || ISSN 2598-0033 (online), http://jurnal.umsu.ac.id/index.php/intiqad DOI: 10.30596/intiqad.v12i2.5089

Vol. 12, No. 2 (December 2020)

milenial seperti hoax tadi, maka bukan tidak mungkin masyarakat Salatiga akan kehilangan gelar "Kota Toleran" di masa depan.

Dari beberapa penelitian yang telah dilakukan, masyarakat Kota Salatiga memiliki berbagai macam strategi untuk melindungi generasi penerus mereka dari ancaman Hoax yang cenderung memecah belah. Salah satu strategi yang cukup dominan dilakukan di antaranya adalah pendidikan toleransi terhadap kalangan Remaja Kota Salatiga, baik secara formal maupun yang informal. Dalam penelitian ini, khusus mengkaji tentang pendidikan toleransi yang dilakukan secara informal, yakni pendidikan toleransi dalam acara-acara perayaan hari-hari besar Islam dan Kristen di Kota Salatiga.

Perayaan hari-hari besar Islam dan Kristen di Desa Pengilon memiliki keunikan tersendiri dibandingkan dengan daerah-daerah lainnya. Selain menjadi ajang refleksi keberagamaan bagi para penganutnya masing-masing, perayaan hari-hari besar Islam dan Kristen, khususnya acara Halal-Bihalal Bersama dan Natal Bersama, juga dijadikan media penanaman nilai-nilai Toleransi di kalangan masyarakat Desa Pengilon.
Pola ini dapat ditemukan dalam keberadaan beberapa sesi tertentu yang dikhususkan sebagai ajang kegiatan bersama antara masyarakat Muslin dan Kristen.

Pada acara Halal-Bihalal Bersama dan Natal Bersama di Desa Pengilon, setidaknya ditemukan dua hal yang kerap dijadikan sebagai media penanaman nilai-nilai toleransi yaitu, pada segi penamaan acara, pra pelaksanaan acara atau persiapan, sesi seremonial, sesi hiburan dan pembagian bingkisan. Pada keempat aspek itulah dijumpai upaya-upaya penegasan tentang penaman nilai-nilai toleransi terhadap kalangan masyarakat Pengilon dan termasuk pada kalangan remaja desa Pengilon.

\section{Internalisasi Nilai Toleransi Melalui}

Penamaan Acara Halal-Bihalal "Bersama” dan Natal "Bersama"

Dari segi penamaan seperti pemberian nama acara dengan HalalBihalal "Bersama" dan Natal "Bersama" menjadi satu simbol bahwa acara tersebut tidak dikhususkan hanya untuk para pemeluk agama masing-masing. Artinya, pembubuhan kata "Bersama" pada acara Halal-Bihalal dan Natal tersebut dimaksudkan agar setiap warga 


\section{INTIQAD: JURNAL AGAMA DAN PENDIDIKAN ISLAM}

ISSN 1979-9950 (print) || ISSN 2598-0033 (online), http://jurnal.umsu.ac.id/index.php/intiqad DOI: 10.30596/intiqad.v12i2.5089

Vol. 12, No. 2 (December 2020)

Pengilon dapat saling mensupport satu sama lain dalam menyukseskan setiap perayaan hari-hari Besar keberagamaan masyarakat Pengilon.

Dalam aspek ini, sudah sangat jelas bahwa perayaan hari-hari besar keagamaan di kalangan masyarakat Pengilon dijadikan sebagai media implementasi nilai-nilai toleransi, termasuk di dalamnya terhadap kalangan remaja Pengilon. Simbol nama tersebut merupakan bentuk "internalisasi" nilainilai Toleransi terhadap remaja di kalangan masyarakat Pengilon.

"Nama itu (peneliti: Halal-Bihalal Bersama dan Natal Bersama) sengaja dibuat demikian Mas. Biar anak-cucu kita tahu bahwa acara Halal-Bihalal dan Natal merupakan hari kebahagian bersama di kalangan masyarakat Pengilon." (Wawancara dengan pak Joko, 2019).

Menurut Ketua RW III Desa Pengilon, Bapak Soekarno, penambahan kata "bersama" pada penamaan HalalBihalal dan Natal tersebut dimulai sejak dirinya menjadi Ketua RT V kurang lebih pada tahun 1998. Menurutnya, konsep acara yang demikian sebenarnya meniru konsep perayaan acara HalalBihalal dan Natal yang dilaksanakan oleh masyarakat Togaten Kota Salatiga, khususnya dalam hal pelibatan warga Kristen dalam acaranya masyarakat Muslim, dan begitu pula sebaliknya. Hal demikian dipercaya telah menjadi media yang cukup efektif dalam menjaga kerukunan antar umat beragama di daerahnya (Wawancara dengan Bapak Sukarno, 2019).

Kedua acara perayaan hari-hari besar keagamaan tersebut tidaklah menjadi satu-satunya media yang dijadikan sebagai ajang penanaman nilai-nilai toleransi di kalangan remaja di Desa Pengilon. Beberapa acara lain yang kerap dijadikan sebagai ajang internalisasi nilai-nilai toleransi di kalangan remaja di Desa Pengilon di antaranya adalah serentetan acara dalam perayaan hari kemerdekaan Indonesia dan HUT Kota Salatiga. Akan tetapi, kultur tersebut telah menjadi kebiasaan masyarakat Kota Salatiga pada umumnya. Sedangkan pelaksanaan Halal-Bihalal Bersama dan Natal Bersama masih dibilang cukup unik di kalangan masyarakat Salatiga dan hanya dilaksanakan di Pengilon dan Togaten.

\section{Nilai-Nilai Toleransi dalam Pra}

Pelaksanaan Acara Halal-Bihalal

\section{Bersama dan Natal Bersama.}




\section{INTIQAD: JURNAL AGAMA DAN PENDIDIKAN ISLAM}

ISSN 1979-9950 (print) || ISSN 2598-0033 (online), http://jurnal.umsu.ac.id/index.php/intiqad DOI: 10.30596/intiqad.v12i2.5089

Vol. 12, No. 2 (December 2020)

Aspek kedua yang cukup dominan menggambarkan tentang penanaman nilai-nilai toleransi pada acara HalalBihalal Bersama dan Natal Bersama adalah pada Pra-Pelaksanaan Perayaan. Nilai-nilai toleransi yang dimaksudkan dalam acara ini di antaranya adalah dari segi penentuan panitia konsumsi; penarikan sumbangan dari seluruh warga Pengilon; penataan tempat acara; serta pengadaan bingkisan dan untuk kalangan anak-anak dan remaja.

Pertama, penentuan panitia Konsumsi. Rapat penentuan panitia konsumsi biasanya dibahas dalam rapatrapat RT yang telah diadakan sebelum pelaksanaan acara perayaan. Dalam pelaksanaannya, sistem penentuan panitia konsumsi biasanya menggunakan sistem persilangan yaitu; ibu Muslim yang akan lebih banyak berperan dalam mempersiapkan konsumsi dalam acara Natal Bersama, sebaliknya Ibu-Ibu Kristiani akan berperan dominan dalam mempersiapkan konsumsi pada acara Halal-Bihalal Bersama.

Sesi ini juga melibatkan remajaremaja perempuan Pengilon. Selain dilatih keterampilan memasak di dapur, sesi ini juga dijadikan sebagai media internalisasi nilai-nilai toleransi. Para remaja perempuan Muslim diajak untuk menyumbangkan tenaganya untuk mensukseskan acara parayaan Natal Bersama, dan begitu pula sebaliknya. Demikian pula, para remaja putera diminta untuk membantu dalam mempersiapkan tempat pelaksanaan upacara perayaan. Keberadaan komunitas Karang Taruna di Desa Pengilon, seperti halnya Karang Taruna di RT V, membantu mengkoordinir kalangan pemuda untuk saling berpartisipasi dalam setiap pelaksanaan upacara perayaan hari-hari besar keagamaan di Desa Pengilon.

"Mereka kita ajak masak-masak mas. Yaa namanya anak muda ya, kadang mereka males-malesan juga. Tetapi, ketika kami rayu mereka dengan bingkisanbingkisan, dan lain sebagainya, akhirnya mereka juga mau membantu. Kadang, kami juga bilang kepada mereka bahwa kalian harus menghargai temanteman bermain kalian yang nonMuslim. Mereka akan sedih kalau kalian tidak mau membantu mereka. Pastinya, mereka akan enggan juga untuk membantu kita." (wawancara dengan Mukhlisah, 2019).

Kutipan tersebut di atas menandakan bahwa penanaman toleransi di kalangan remaja Desa Pengilon dimulai dari keluarga, khususnya 


\section{INTIQAD: JURNAL AGAMA DAN PENDIDIKAN ISLAM}

ISSN 1979-9950 (print) || ISSN 2598-0033 (online), http://jurnal.umsu.ac.id/index.php/intiqad DOI: 10.30596/intiqad.v12i2.5089

Vol. 12, No. 2 (December 2020)

bagaimana orang tua mendidik putraputerinya. Tidak jarang juga para remaja yang enggan bergabung dan berpartisipasi dalam berbagai kegiatan. Alasannya bermacam-macam, ada yang karena malu, ada yang fokus sekolah, dan berbagai macam alasan lainnya. Tetapi, meski mereka tidak bisa berpartisipasi dalam mempersiapkan konsumsi, sebagian besar remaja perempuan pasti hadir pada hari pelaksanaan upacara.

Kedua, penarikan sumbangan dari seluruh warga Pengilon. Setiap menjelang pelaksanaan upacara hari-hari besar Islam dan Kristen, kurang lebih satu bulan sebelum pelaksanaan acara perayaan, biasanya ada petugas yang akan mendatangi rumah seluruh warga Pengilon untuk menagih sumbangan. Sumbangan dalam acara tersebut sifatnya tidak mengikat dan lebih didasarkan pada keikhlasan masingmasing warga. Tidak jarang juga beberapa warga yang secara ikhlas mengeluarkan sumbangan dalam bentuk snack. Hasil sumbangan tersebut, selain digunakan untuk kebutuhan konsumsi juga digunakan untuk pangadaan berbagai macam bingkisan.
Ketiga, penataan tempat acara. Penataan tempat acara, dari mendirikan tenda, pendirian dan penataan panggung, peminjaman kursi dan sound system, dekorasi, dan lain sebagainya, sebagian besar menjadi tanggung jawab laki-laki, termasuk seluruh kalangan remaja lakilaki di pengilon. Remaja Muslim dan Kristen saling bahu membahu dalam mempersiapkan dan mendukung setiap pelaksanaan upacara perayaan hari-hari besar keagamaan di Desa Pengilon.

Keempat, pengadaan bingkisan dan hadiah untuk kalangan anak-anak dan remaja di Desa Pengilon. Kaum remaja Kristiani sudah sangat populer dengan bingkisan dan hadiah pada perayaan natal. Melalui hadiah dan bingkisan Natal tersebut, Kalangan remaja Kristen diajari tentang nilai-nilai solidaritas dan pengorbanan. Akan tetapi, jika bingkisan Natal pada umumnya hanya dapat dibagikan untuk anak-anak dan remaja Kristen saja, tapi dalam pelaksanaan Natal bersama justru mereka diajari untuk berbagi dengan teman sebayanya dari kalangan Muslim. Mereka diajari bagaimana menyisihkan sebagian hartanya untuk berbagi dengan temantemannya, termasuk teman-teman 


\section{INTIQAD: JURNAL AGAMA DAN PENDIDIKAN ISLAM}

ISSN 1979-9950 (print) || ISSN 2598-0033 (online), http://jurnal.umsu.ac.id/index.php/intiqad DOI: $10.30596 /$ intiqad.v12i2.5089

Vol. 12, No. 2 (December 2020)

Muslim sebayanya (Wawancara dengan Ester Ika, 2019).

Sedangkana di kalangan umat Islam, para remaja Muslim telah cukup akrab dengan istilah amplop lebaran. Hampir serupa dengan tradisi berbagi bingkisan dalam umat Kristiani, tradisi berbagi di lebaran juga sarat dengan makna berkorban dan berbagi dengan orang lain. Tradisi semacam inilah yang kemudian diterapkan juga pada perayaan Halal-Bihalal Bersama, tapi bentuknya sudah berupa bingkisan hadiah. Para remaja Muslim dan Kristem yang hadir dalam acara Halal-Bihalal Bersama masing-masing akan mendapatkan hadiah dan bingkisan.

Terlepas dari hal itu, tradisi pembagian hadiah dan bingkisan dalam acara halal-bihalal Bersama dan Natal Bersama tersebut dimaksudkan untuk menarik perhatian anak-anak dan remaja agar mereka mau saling terlibat dan saling berpartisipasi, setidaknya mau hadir, dalam setiap pelaksanaan acara perayaan Halal-Bihalal bersama dan Natal Bersama di kalangan Masyarakat Pengilon (Wawancara dengan Ketua RW III Pengilon, 2019).

\section{Pendidikan Toleransi pada Sesi} Seremonial Acara Perayaan

Kultur penanaman nilai-nilai toleransi di kalangan remaja di Desa Pengilon sudah terbentuk sejak lama. Hal ini terlihat pada sesi seremonial setiap pelaksanaan acara nonkeagamaan, seperti halnya perayaan HUT Kemeredekaan Republik Indonesia. Dalam acara-acara nonkeagamaan, para remaja Kristen dan Muslim saling bahu membahu dalam mensukseskan acara. Salah satu contoh kasus misalnya pada parayaan HUT RI pada tahun 2019. Pembawa acaranya dibawakan oleh dua remaja perempuan Pengilon yang berbeda agama, yakni Kristen dan Islam.

Berbeda dengan acara seremonial pada acara perayaan Kemerdekaan Agustus tersebut, pembawa acara dalam perayaan hari-hari besar keagamaan dipercayakan kepada remaja penganut agamanya masing-masing. Hal demikian merupakan implementasi dari sikap menghargai akan arti penting dan sakralitas perayaan keagamaan bagi masing-masing pemeluknya. Meski demikian, para pemuda Kristen dan Muslim saling mensupport satu sama 


\section{INTIQAD: JURNAL AGAMA DAN PENDIDIKAN ISLAM}

ISSN 1979-9950 (print) || ISSN 2598-0033 (online), http://jurnal.umsu.ac.id/index.php/intiqad DOI: 10.30596/intiqad.v12i2.5089

Vol. 12, No. 2 (December 2020)

lain, misalnya dengan diadakannya rapat dan musyawarah pra pelaksanaan acara.

Pendidikan Toleransi pada Sesi Pembagian Hadiah atau Bingkisan Sebagaimana telah disebutkan sebelumnya bahwa sesi pembagian hadiah dan bingkisan, baik dalam acara Halal-Bihalal Bersama dan Natal Bersama, dimaksudkan untuk memotivasi kalangan anak-anak dan remaja Pengilon agar bersedia hadir dalam masing-masing perayaan hari-hari besar keagamaan. Di samping itu, sepirit utama yang ingin dibangun dalam sesi ini adalah solidaritas sosial, siap berkorban dan berbagi dengan orang lain, dan menikmati hari-hari kebahagiaan secara bersama-sama antara remaja Muslim dan Kristen.

\section{Simpulan}

Kota Salatiga mendapatkan Gelar sebagai Kota Toleran nomor 2 di Indonesia dilatar belakangi oleh kultur kehidupan toleran yang telah mengakar dalam kehidupan sehari-hari masyarakat Kota Salatiga. Salah satu faktor yang cukup berperan besar dalam pelestarian kultur toleransi di antaranya adalah dengan cara memasifkan pendidikan nilai-nilai toleransi, baik secara formal maupun non-formal, terhadap kalangan anak-anak dan remaja Kota Salatiga.

Kultur pendidikan toleransi nonformal yang sampai saat ini dilakukan dan dianggap efektif untuk kalangan remaja Kota Salatiga, khususnya di kalangan remaja Desa Pengilon, adalah pada perayaan hari-hari besar keagamaan seperti halnya Halal-Bihalal Bersama dan Natal Bersama.

Pada acara Halal-Bihalal Bersama dan Natal Bersama, setidaknya terdapat beberapa sesi penting yang selama ini sering dijadikan media pendidikan atau penanaman nilai-nilai toleransi terhadap kalangan remaja di Desa Pengilon Kelurahan Mangunsari Kecamatan Sidomukti Kota salatiga. Beberapa sesi yang dimaskudkan di antaranya adalah pada aspek penamaan acara dengan sebutan Halal-Bihalal "Bersama" dan Natal "Bersama"; pra-pelaksanaan atau persiapan acara; sesi seremonial; dan yang terakhir adalah pada sesi pembagian hadiah dan bingkisan.

\section{E. Daftar Pustaka}

Maskuri, Abdullah. (2001). Pluralisme Agama dan Kerukunan dalam 


\section{INTIQAD: JURNAL AGAMA DAN PENDIDIKAN ISLAM}

ISSN 1979-9950 (print) || ISSN 2598-0033 (online), http://jurnal.umsu.ac.id/index.php/intiqad DOI: 10.30596/intiqad.v12i2.5089

Vol. 12, No. 2 (December 2020)

Keagamaan. Jakarta: Penerbit Buku Kompas.

Al Munawar, Said Agil Husain. 2005.

Fikih Hubungan Antar Agama, Jakarta: Ciputat Perss.

Ajat Sudrajat, 2008. Din Al Islam, Yogyakarta UNY Press.

Arijal, Hasbi. (2015). "Problem-Problem Monoteisme dalam Agama-Agama Semit". Jurnal Kalimah, 13(1).

Depdikbud RI, 1990. Kamus Besar Bahasa Indonesia, Jakarta : Balai Pustaka.

Hasyim, Umar. (1979). Toleransi dan Kemerdekaan dalam Islam: Sebagai Dasar Menuju Dialog dan Kerukunan Antar Agama. Surabaya Imaroh, Muhammad. (1999). Islam dan Pluralitas. Jakarta: Gema Insani Press.

Kartono, Kartini. (1990). Pengantar Metodelogi Riset Sosial, Bandung, Mandar Maju.

Kenneth, W. Morgan. (1963). Islam Jalan Lurus, terj. Abu Salamah dan Chaidir Anwar, Jakarta: Pustaka Jaya.
Kusumawardani, A, dkk., Nasionalisme, (Buletin Psikologi, Tahun XII, No. 2, Desember 2004)

Ma'arif, Syamsul. (2005). Pendidikan Pluralisme di Indonesia. , Yogyakarta: Logung Pustaka.

Madjid, Nurcholis. (1993). Islam Kerakyatan dan Keindonesiaan Pemikiran Nurcholis Muda. , Bandung: Mizan.

Marimba, Ahmad. (1986). Pengantar Filsafat Islam. Bandung: $\mathrm{Al}$ ma'arif.

Muhajir, Noeng. (2002). Metodologi Penelitian Kualitatif. Yogyakarta: Rake Sarasin.

Munir, Abdul. (1989). Pokok-pokok Ajaran NU. Solo: Ramdhani.

Nasution, S. (1988). Metode Penelitian Naturalistik Kualitatif. Bandung: PT. Tarsito.

Porwadarminta, W.J.S. (1986). Kamus Umum Bahasa Indonesia. Jakarta: Balai Pustaka.

Rahmat, M. Imadadun. (2003). Islam Pribumi Mendialogkan Agama, Membaca Realita. Jakarta: Erlangga,. 
Risdianto, Heri. (2008). Kerukunan

Umat Beragama (Studi Hubungan

Pemeluk Buddha dan Islam di

Desa Jatimulyo, Kec. Girimulyo,

Kab. Kulon Progo), Yogyakarta:

UIN Sunan Kalijaga, Jurusan

Perbandingan Agama, Fakultan

Ushuluddin.

Ritter, Herry. (1986). Dictionary of Concepts in History, New York: Greenwood Press.

Stevens, Kate L. (2006). Hubungan Antara Orang Kristen dan Islam di Indonesia (Studi Kasus: Universitas Muhammadiyah Malang), Malang: Universitas Muhammadiyah Malang, Fakultas Ilmu Sosial dan Ilmu Politik.

Sukmadinata, Nana Syaodih. (2005).

Metode Penelitian Pendidikan.

Bandung: Pascasarjana UPI \& PT.

Remaja Rosdakarya. 